\title{
Effectiveness of two treatments to promote tree regeneration: implications for forest restoration in the Isla del Coco National Park, Costa Rica
}

\section{Luis Acosta-Vargas ${ }^{1 *}$, Adriana E. Rovere ${ }^{2} \&$ Jorge Camacho-Sandoval ${ }^{3}$}

1. Instituto Tecnológico de Costa Rica; Doctorado en Ciencias Naturales para el Desarrollo (DOCINADE), Instituto Tecnológico de Costa Rica, Universidad Nacional, Universidad Estatal a Distancia, Costa Rica; lacosta@tec.ac.cr, acosta.luisguillermo@gmail.com

2. INIBIOMA, CONICET-Universidad Nacional del Comahue. Centro Regional Universitario Bariloche, Argentina; adrirovere@gmail.com

3. Instituto Tecnológico de Costa Rica; jorge.camacho.s@gmail.com

* Correspondence

$$
\text { Received 29-I-2019. Corrected 27-IV-2019. Accepted 01-X-2019. }
$$

\begin{abstract}
Introduction: Isla del Coco is the only island in the Eastern Tropical Pacific with humid tropical forests; 296 plant species are reported, of them, $22 \%$ are endemic. Their ecology is poorly understood. Deforestation and the introduction of rats, feral pigs and white-tailed deer are the primary agents of forest degradation. After more than 120 years, the deforested areas have never recovered the native forest. Objective: To analyse if the deforested area keeps its resilience, we evaluated the natural regeneration and ecological processes associated. Methods: From August 2016 to June 2018, we conducted a restoration experiment consisting of a randomized complete blocks design including vegetation cutting, vegetation uprooting and controls as treatments. Plots were protected with an exclusion fence to avoid herbivores. Results: There were no differences between plant cutting and uprooting in stimulating natural regeneration. We only recorded the seedlings of two tree species, 35 individuals of Cecropia pittieri and three of Sacoglottis holdridgei, both endemic. Their regeneration established during the first 15 months mainly. At the end of the experiment, the structure and composition of the vegetation changed from bushes dominated by Entada gigas $(28 \%)$ and Clidemia strigillosa $(12 \%)$ to grasses dominated by Paspalum conjugatum (39\%). Entada gigas has a high recolonizing potential with a growing rate of $1.6 \pm 0.2 \mathrm{~m} /$ month. Conclusions: As filters for restoration we determined herbivores, which pose a strong negative impact in the development of the forest; the exhausted seed bank of tree species and scarce or null seed dispersion.
\end{abstract}

Key words: herbivory, Isla del Coco, natural regeneration, restoration, white-tailed deer, feral pig.

Acosta-Vargas, L., Rovere, A. E., Camacho-Sandoval, J. (2020). Effectiveness of two treatments to promote tree regeneration: implications for forest restoration in the Isla del Coco National Park, Costa Rica. Revista de Biología Tropical, 68(Suppl. 1), S103-S114.

Isolation has guided the evolution of species and ecosystems in islands, allowing the development of particular fauna and flora and endemism (Losos \& Ricklefs, 2009). But at the same time, isolation and the small size of insular ecosystems make them highly fragile, in most cases, to climate changes and exotic species introduction. This is because their equilibrium thresholds brake easily and the species are prone to extinction. According to reports, $75 \%$ of the extinctions have occurred in islands, while $67 \%$ were due to the introduction of species (Donlan et al., 2000; Sánchez Pacheco, Tershy, \& Aguilar, 2000).

The adverse effects of invasive species on insular ecosystems and on native species are 
supported by several investigations that report stagnation or sequestration of the processes of succession, alterations to biodiversity and loss of productivity of the ecosystems. These effects have been quantified by the grazing rate, niche occupation, loss and displacement of species, among others (Gill \& Beardall, 2001; Green, O’Dowd, \& Lake, 1997; Koda \& Fujita, 2011; O'Dowd, Green, \& Lake, 2003; Rooney \& Waller, 2003).

Restoration programs have been led in many islands, and efforts include several different initiatives, the most important being the control and eradication of fauna (Veitch, Clout, Martin, Russell, \& West, 2019); the introduction of fauna in islands represents the main threat for islands' native biodiversity (Jones et al., 2016). Similarly, efforts have been made where the objective has been the forest, as in the case of the Galapagos Islands (SmithRamírez, Vargas, Castillo, Mora, \& Arellano-Cataldo, 2017) and Hawaii (Friday et al., 2015; Weller et al., 2018). As other efforts in restoration and eradication, they are expensive (Capizzi, Baccetti, \& Sposimo, 2010; Donlan, Luque, \& Wilcox, 2015; Goldstein, Pejchar, \& Daily, 2008). In large-scale forest restoration, natural regeneration plays a significant role in reduction of costs and field efforts (Chazdon \& Guariguata, 2016). Passive restoration based on natural regeneration supposes the presence and functioning of specific ecological processes such as seed dispersal, a viable seed bank and dispersers. In islands, some of those ecological processes are absent (Madriz-Masís 2009), becoming filters for restoration. For these reasons, the evaluation of ecological processes is fundamental before implementing a large-scale forest restoration.

At $500 \mathrm{~km}$ from Costa Rica's mainland, Isla del Coco National Park (PNIC in Spanish) receives an annual rainfall that ranges between 5000-7 $000 \mathrm{~mm}$ (Alfaro, 2008) allowing the growth of tropical humid forests. Plant diversity reports 296 species, of which 96 are pteridophytes (ferns), 196 angiosperms, and six lycophytes. There are 48 endemic species (22\% of the native flora); of these, 28 (58\%) are pteridophytes, 18 (38\%) angiosperms and 2 (4\%) lycophytes (Estrada-Chavarría, SánchezGonzález \& Rodríguez-González, 2020). The tree endemic species include Cecropia pittieri B. L. Rob., 1912 and Sacoglottis holdridgei Cuatrec., 1964 (Trusty, Kesler, \& Delgado, 2006). The high humidity favoured fern diversity which reaches the $50 \%$ of the endemism, a condition that has not been observed in any other oceanic island (Trusty et al., 2006). This particular situation represents a significant contribution to global biodiversity (Sánchez Pacheco et al., 2000).

The introduction of exotic species is one of the main milestones concerning ecosystems degradation. In the PNIC, 77 potentially invasive plant species have been reported (Estrada-Chavarría et al., 2020). Additionally, rats (Rattus rattus and $R$. norvegicus) and feral pigs (Sus scrofa) were introduced in 1973, and cats (Felis silvestris catus) and white-tailed deer (Odocoileus virginianus) in 1934. In addition, 10.6ha were deforested in Chatham Bay between 1879 and 1881 to establish a penal colony, and 35 ha in Wafer Bay between 1894 and 1906, to establish an agricultural colony lead by Augusto Gissler (Montoya, 2016).

The areas abandoned for more than a century were unable to recover the native forests, and the effects of deforestation and introduced fauna are still visible in the landscape of the PNIC. Moreover, other investigations report harmful effects on soil erosion (Sierra, 2001), and the alteration in regeneration patterns and forest structure, caused by selective herbivory on some tree species (Acosta-Vargas, 2016; Montoya, 2016; Bonilla-Mata \& Acosta Vargas, 2020). These impacts are evident, although the effects of deforestation and its synergy with the introduction of flora and fauna in the PNIC have been scarcely studied.

As an effort for studying and recovering the forest, an initiative to control the species introduced and to restore the native forests in the deforested areas in Chatham Bay and Wafer Bay took place in 2004 in the PNIC. This initiative contributed valuable information on forest structure, flora diversity and 
introduced fauna population, setting in this way the baseline for monitoring. Unfortunately, the main goal of ecosystem restoration was not achieved, and ecosystem degradation still occurs nowadays (Madriz-Masís, 2009; G. Blanco, personal communication, 2017). Ecological processes and species ecology in Isla del Coco are poorly understood, therefore become a priority in guiding the efforts towards restoration and conservation.

As deforestation and invasive species have altered native ecosystem resiliency in the PNIC, this work aimed to evaluate the effects of different treatments on the natural regeneration of native tree species, seeking the answer to: 1) How much are herbivores affecting tree regeneration?; 2) How is the site recolonizing and changing its vegetation cover?; 3) Which are the filters acting against the natural regeneration?; 4) How can we lead the restoration of the site? We hypothesized that light availability and herbivores are the main factors affecting the natural regeneration of tree species and that, therefore, removing these filters is the first step to restore deforested areas.

\section{MATERIALS AND METHODS}

Area of study: Isla del Coco is an oceanic island located in Eastern Tropical Pacific, and the only with tropical humid forest (UNESCO, 2019), its area is $24 \mathrm{~km}^{2}$, and it is located 500 $\mathrm{km}$ southwest of the Costa Rican landmass, between $5^{\circ} 30^{\prime}-5^{\circ} 34^{\prime} \mathrm{N}$ and $87^{\circ} 01^{\prime}-87^{\circ} 06^{\prime} \mathrm{W}$ (Cortés, 2008); it is the only emerging point of the Cocos Ridge (Rojas \& Alvarado, 2012). The PNIC is within the Intertropical Convergence Zone; the average annual temperature is $25.5^{\circ} \mathrm{C}$, and the annual precipitation ranges between 5000-7000 mm (Herrera, 1986). Isla del Coco was declared National Park in 1978, and it is a UNESCO World Heritage Site since 1997.

The selected area of study is on the northeast side of the Aguacate Sector, Chatham Bay. It consists of 10 ha that were deforested in 1881 to build a penal colony later abandoned (Montoya, 2016). Currently, the area exhibits a relatively homogeneous native vegetation cover including bushes like Clidemia strigillosa (Sw.) Dc. 1828 (Melastomataceae), grass Hypolytrum amplum Poepp. \& Kunth, 1837 (Cyperaceae) and the vine Entada gigas (L.) Fawc. \& Rendle 1920 (Fabaceace).

Experimental design: We used complete randomized blocks design. Four blocks were set up in the field in August 2016. The selection criterion for block location in the area of study was slopes $<40 \%$. The blocks were located randomly among the possible location points and oriented following the level curves to give them the same conditions of fertility and humidity. The experimental unit consisted of $10 \times 10 \mathrm{~m}$ plots delimited in the field. Each experimental unit hosted a different randomly assigned treatment. An exclusion fence $1.7 \mathrm{~m}$ high was set up around each block of 10x30m to prevent feral pigs (Sus scrofa Linnaeus 1758) and white-tailed deer (Odocoileus virginianus Zimmermann 1780) from coming in.

The treatments applied were: 1) Vegetation cutting within the exclusion fence (VCwEx), where the vegetation was cut at ground level, allowing the entry of light, freeing space and improving nutrient availability; 2) Vegetation uprooting within the exclusion fence (VUwEx), where the plants were uprooted and shaken to leave the soil in the area of the treatment to allow the entry of light, free space, improve nutrient availability and stir the soil to expose the buried seed bank; 3) Positive control within the exclusion fence ( $\mathrm{CwEx})$, to avoid the herbivore effect; 4) Negative control outside the exclusion fence (CoEx), to maintain the permanent disturbance condition of the site under study; 5) Vegetation cutting outside exclusion fence (VCoEx), where the effect of herbivores on the establishment of tree species was evaluated and was applied 11 months later, guided by the preliminary results of the trial. The order of the treatments was randomized in each block (Fig. 1).

Data collection: The experimental period was from August 2016 to July 2018, measurements were made every four months on 


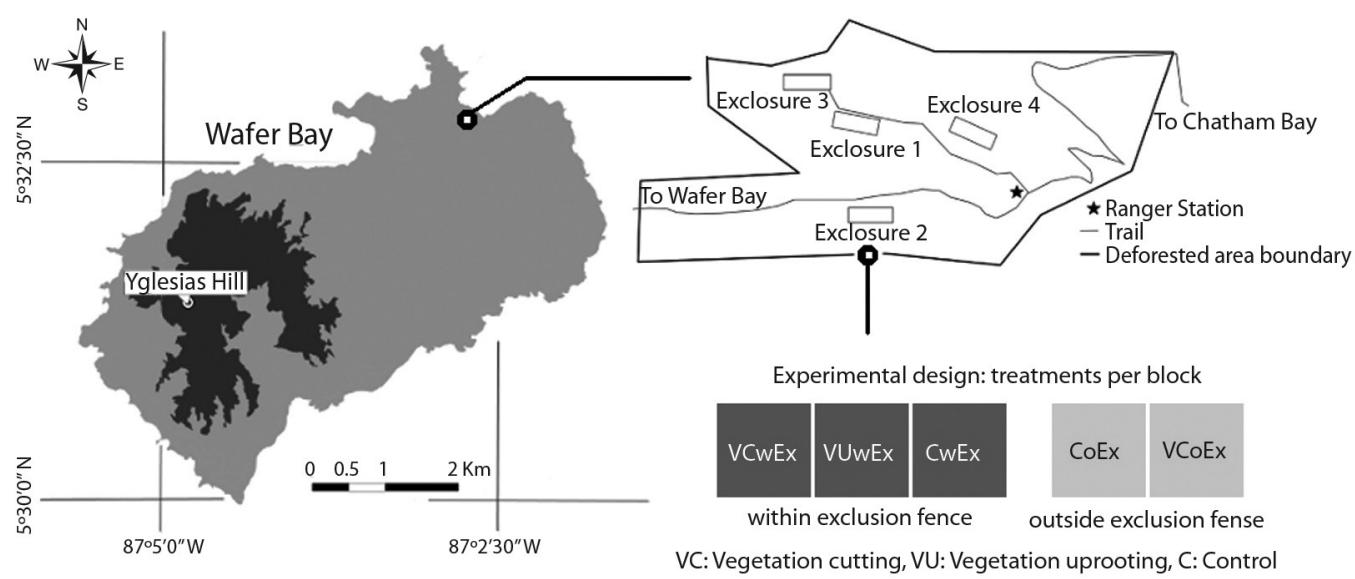

Fig. 1. Distribution of blocks and treatments in the study area. Isla del Coco National Park, Costa Rica, 2018.

average, with a total of five measurement dates. In each visit, we identified seedlings of tree species and marked every tree with a unique code on an aluminium tag. We surveyed each tree height $(\mathrm{m})$ utilizing a telescopic rod, and the diameter $(\mathrm{mm})$ for trees $>1.5 \mathrm{~m}$ high at $1.3 \mathrm{~m}$ height using a diametric tape.

We used the Braun-Blanquet scales (Newton, 2007) for estimating herbaceous and litter cover, bare soil and rocks. Ten 1x1m sampling points were located randomly in each experimental unit, leaving one meter around to avoid the border effect.

To assess the ability of colonizing from the border of the remaining original vegetation, we measured the shoots of the liana Entada gigas coming over the fence; the variables were total shoot length (m), and number and length $(\mathrm{m})$ of the secondary shoots.

The Shapiro Wilk test (Shapiro \& Wilk, 1965) was applied to determine the normality of the data and the Levene test (Levene, 1961) for homoscedasticity. The analysis of the results of the trial to determine the effectiveness of the treatments was performed employing an analysis of variance (ANOVA) if the assumptions of normality and homoscedasticity were not fulfilling, we used the Friedman test instead (Friedman, 1937).

We used multivariate analysis to determine the changes in the vegetation cover relative to composition and abundance of species. We used the tests described by Clarke (1993), Non-metric Multidimensional Scaling (NMDS), which use a Bryan Curtis similarity matrix that allows null values; the Analysis of Similarity (ANOSIM) test to determine the similarities between the vegetation cover of the different treatments and the Similarity Percentage Analysis (SIMPER) to identify the species that contribute to dissimilarity. For all cases Bray-Curtis distances and 9999 permutations were used. The data were analysed utilizing the PAST statistical software version 3.21, released in October, 2018 (Hammer, Harper, \& Ryan, 2001).

\section{RESULTS}

Regeneration of tree species: There were no differences in the treatments plant cutting and uprooting in stimulating tree species regeneration (Friedman $=0.35$ ). Controls within the exclusion fence (CwEx) had two individuals, but as they were on the border, it cannot be attributed to treatments, while no regeneration was observed in the controls outside the exclusion fence (CoEx) (Table 1 in Digital Appendix).

During the experimental period of 22 months, 63 individuals of two endemic tree species were recorded, 58 of C. pittieri and five of S. holdridgei. Of them, two individuals were already in the site and three germinated 
from the soil seed bank. Two months after the experiment started, $C$. pittieri, along with some pastures, regenerated in the sites; at seven months, corresponding to the time of most significant recruitment of regeneration, 32 individuals were recorded with an average height of $43.8 \pm 9.8 \mathrm{~cm}(\mathrm{n}=32 ; \mathrm{SD}=28.16)$. At 15 months, 49 individuals were still alive, declining to 38 individuals at 22 months (Fig. 2 ), distributed in 35 trees (437.5 trees/ha) of C. pittieri and three (37.5 trees/ha) of $S$. holdridgei, with an average height of $2.37 \pm 0.43 \mathrm{~m}$ $(\mathrm{n}=42, \mathrm{SD}=1.43)$.

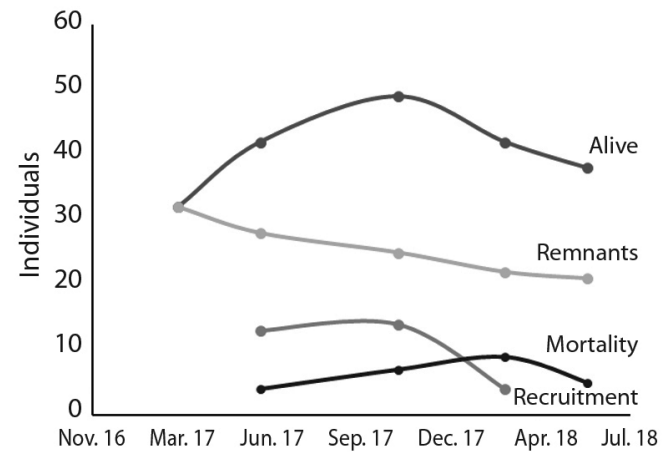

Fig. 2. Regeneration, recruitment and mortality of tree species recorded in the restoration trial. Isla del Coco National Park, Costa Rica, 2018.

Of the 63 individuals recorded, 21 were monitored in all five measurements; between the second and fourth measurement, 31 trees were recruited (Fig. 2). Mortality was recorded in all measurements and presented no regular pattern. At the end of the experimental period, 25 individuals of $C$. pittieri were recorded dead; of these, 21 died due to random causes, and the remaining four seedlings recorded in the vegetation cutting outside exclusion fence (VCoEx) treatment, were consumed by herbivores; no more individuals were registered in this treatment (VCoEx).

Change of vegetation cover: After 22 months of the experimental period, the experimental units where vegetation cutting, and uprooting were applied within the exclusion fences were able to recover $100 \%$ of the vegetation cover, while the control maintained the original vegetation cover. In terms of vegetation cover, there were no differences between treatments (Friedman, $\mathrm{p}>0.05$ ). However, the vegetation community presented changes in the structure and species composition between control, and plant cutting and uprooting.

Eighteen species were recorded (Table 2 in Digital Appendix). Regarding structure, the vegetation changed from a closed bush cover as high as $1.5 \mathrm{~m}$ of $C$. strigillosa and H. amplum, to a dense pasture cover and some herbaceous plants and ferns up to $60 \mathrm{~cm}$ high, dominated by Paspalum conjugatum P. J. Bergius 1772 and (S1 in Digital Appendix).

The NMDS suggests the formation of two groups ( stress=0.12, Fig. $3 \mathrm{~A}$ ) due to the changes that occurred in the species composition. The
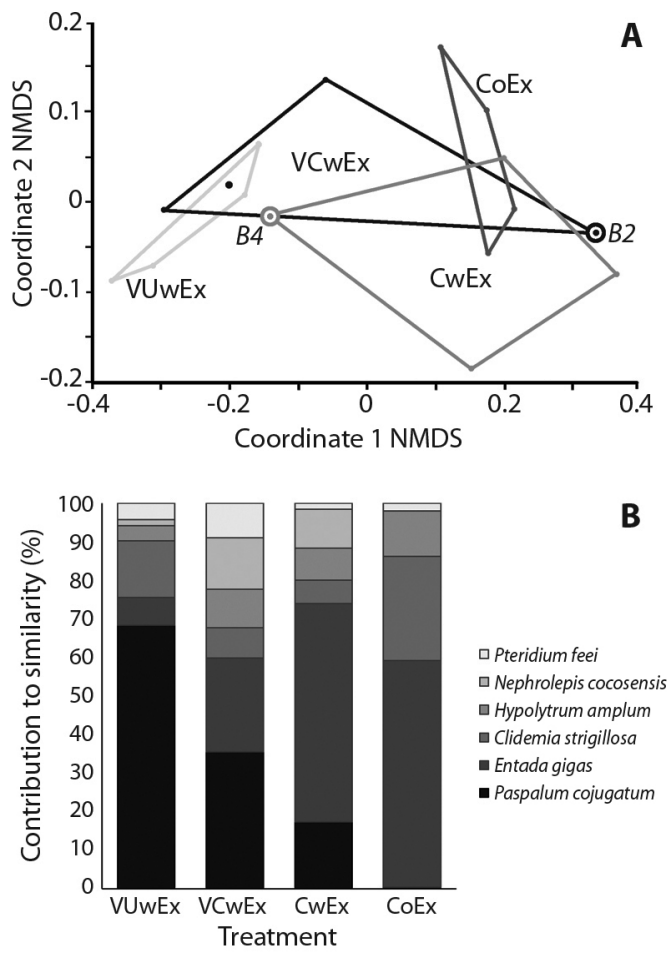

Fig. 3. Results of the multivariate analysis. A. Nonmetric multidimensional scaling (NMDS) grouping of the vegetation cover; B. Percentage of contribution of the six main species that establish the similarity at $34.77 \%$, determined by the Similarity Percentage Analysis (SIMPER) among the treatments evaluated in the restoration trial. Isla del COCO National Park, Costa Rica, 2018. 
first group corresponds to the vegetation cover established in the experimental units where vegetation cutting, and vegetation uprooting treatments were applied, while the second group corresponds to the original vegetation cover present in the control outside exclusion fence and three of the controls within the exclusion fence (CwEx). The control within exclusion fence from Block 4 changed its vegetation cover, becoming more related to the group of cutting and uprooting treatments; similarly happens with vegetation cutting within the exclusion fence (VCwEx) in Block 2, where the vegetation cover changed, resembling that of the controls (CwEx, CoEx) (Fig. 3A). The ANOSIM test (9999 permutations) showed that the groups suggested by the NMDS analysis presented differences between their samples $(\mathrm{p}=0.03)$, although the dissimilarity is low (ANOSIM R $=0.29$ ), occurring between control outside the exclusion fence (CoEx) and vegetation uprooting within the exclusion fence (VUwEx, $\mathrm{p}=0.03$ ).

The dissimilarity between CoEx and VUwEx analysed by the SIMPER test was $80.24 \%$, explained by three species: P. conjugatum at $39 \%$, E. gigas at $28.19 \%$ and $C$. strigillosa at $12.4 \%$ (Fig. 3B, Table 2 in Digital Appendix). The global similarity among treatments was of $26.08 \%$.

Site reoccupation by species of the original vegetation cover: $E$. gigas, $C$. strigillosa and $H$. amplum were unable to recolonize the site after treatment application by seed bank or sprouting (Fig. 3). Entada gigas showed high site reoccupation capacity from the border of the remaining original vegetation outside the plots. This vine reported main shoot growth of $1.6 \pm 0.2 \mathrm{~m} /$ month $(\mathrm{n}=38, \mathrm{SD}=0.62)$, producing an average $6.7 \pm 1.6(\mathrm{n}=38, \mathrm{SD}=4.58)$ secondary shoots with an average length of $1.2 \pm 0.27 \mathrm{~m}$ $(\mathrm{n}=38, \mathrm{SD}=0.82)$.

\section{DISCUSSION}

Effect of treatments on the regeneration of tree species in the PNIC: We did not find statistical differences between the uprooting and cutting vegetation treatments, both were successfully activating the natural regeneration. But, the effect of the herbivores was evident when comparing against treatments outside the fence where a few seedlings were reported that were later grazed. These results prove our hypothesis that herbivory and the availability of light are filters to the recovery of the site. However, registering $95 \%$ of the seedlings of a single species ( $C$. pittieri), is a fact that indicates that there are other filters to overcome for restoring the site, related to the ecology of the species and the lack of ecological processes. Finding and understanding how those filters are acting is mandatory before putting into practice any large-scale restoration initiative, in order to achieve success, due to the associated costs and efforts (Donlan et al., 2015).

Herbivores effect: The herbivores introduced into the PNIC have a strong impact on forest regeneration. The harmful effect of herbivores in islands has been studied in different parts of the world and has been confirmed employing exclusion fences (Côté et al., 2014; Relva, Nunez, \& Simberloff, 2010). The results obtained confirm the intense pressure posed by herbivores since the regeneration of tree species took place only inside the exclusion fences, but was missing in the treatments outside the exclusion fence. For instance, in the cutting treatment outside the exclusion fence, regeneration of $C$. pittieri and $S$. holdridgei was recorded in the first measurement, while in the second measurement the regeneration marked was not there and signs of the presence of white-tailed deer in the experimental units were found (S2 in Digital Appendix). Consistently, no tree seedlings were recorded in the four experimental units of vegetation cutting outside exclusion fence (VCoEx), confirming that these species are palatable. Furthermore, rangers reported herbivores consuming $C$. pittieri and S. holdridgei (G. Blanco, personal communication, 2017).

Site recolonization: E. gigas, $H$. amplum and $C$. strigillosa are the dominant species in the trial area (Fig. 3B, control outside 
exclusion; S1 in Digital Appendix). After occupying the site for an extended period, the prediction was that these same species would re-establish in the place once the vegetation cutting and uprooting treatments were applied. However, the prediction proved wrong, demonstrating a low capability of these species to regenerate from the seed bank or by sprouts, except for E. gigas, whose great potential for growing from the borders of the original vegetation cover required control on the fences.

Another factor influencing the change in vegetation cover was high availability of viable seeds of the stoloniferous grass $P$. conjugatum in the soil seed bank. Paspalum conjugatum was not recorded at the time of applying the treatments vegetation cutting and uprooting. Paspalum conjugatum showed a high capability of site occupation, reaching $55 \%$ of the vegetation cover after seven months; it has high growth rates in the site, creating a dense mantle. Other studies reported that pastures represent an adverse effect on forest regeneration, composition and structure (Flory \& Clay, 2010b, 2010a; Litton, Sandquist, \& Cordell, 2006). According to the pattern observed and reported, $P$. conjugatum is obstructing the establishment of regeneration of $C$. pittieri, mainly. This effect of $P$. conjugatum is confirmed by the decrease in recruitments from 15 months to 22 months, as no additional $C$. pittieri individuals were recorded in that period (Fig. 2). The dense mantle created by P. conjugatum grows up to $60 \mathrm{~cm}$ high, impeding light entry and suppressing any germinating seedling. Therefore, this situation implies that a new intervention is needed, either controlling $P$. conjugatum or planting trees higher than $50 \mathrm{~cm}$, which is on average the height $P$. conjugatum reached, as a strategy to restore the site.

Paspalum conjugatum and E. gigas are the most important species when it comes to defining the changes recorded in the vegetation cover (Fig. 3B) and are to be given priority when defining successful restoration indicators, because of their capability to stop and modify the natural regeneration of tree species in the PNIC.
Filters detected for natural regeneration: The process of natural regeneration is influenced by multiple biotic and abiotic factors (Whitmore, 1998). The results suggest that herbivory and the ecological process of seed dispersal and seed bank viability are the major filters preventing the natural regeneration of native tree species in Isla del Coco. This fact restricts ecological processes because of the absence of key species or functional groups on the island (Cushman, 1995). There are 16 tree species reported in the forests of the PNIC (Porras Jiménez, 2012; Porras-Jiménez, Acosta-Vargas, Castillo-Ugalde, \& Quesada-Monge, 2014); of these, only $C$. pittieri with 58 individuals and $S$. holdridgei with five individuals reported regeneration in this trial, indicating poor seed bank and absence of seed dispersal for tree species. Analysing the seed dispersal mechanisms and seed bank response according to seedling emergence of $S$. holdridgei and $C$. pittieri, we can draft a first theory to understand their success in occupying the site.

Sacoglottis holdridgei is the most abundant and vital canopy species. As happens with other species of the family Humiriaceae, because of the fruit type and size, seed dispersal must be carried out by mammals and some specific birds (Hammel, Grayum, Herrera, \& Zamora, 2015; Bufalo, Galetti, \& Culot, 2016; Fernández-Vega, Covey, \& Ashton, 2017). These dispersers are not found in Isla del Coco. Therefore, the dispersion for S. holdridgei is limited to gravity and the action of water, as reported for continental Sacoglottis trichogyna Cuatrec. 1968 (Hartshorn, 1978). These seed dispersal mechanisms are insufficient to colonize the deforested areas in the PNIC, where forest loss came from the high area of the mountain down to the base, and lateral dispersion is unlikely ( $\mathrm{S} 3$ in Digital Appendix).

Cecropia pittieri showed the highest regeneration rates, although the spatial distribution is irregular and independent of whether or not there are mother trees close to the trial areas. The genus Cecropia is dispersed by bats (Horsley, Bicknell, Lim, \& Ammerman, 2015), who help seed germination as the seeds pass 
through the digestive tract (Carvalho, Silva, Rocha, \& Almeida, 2018). Bats, however, are not found in the PNIC (I. Chinchilla, personal communication, 2017). According to reports, Cecropia seeds are also dispersed by birds and mammals (Fleming \& Williams, 1990; Medellin, 1994). Coco's finch (Pinaroloxias eplete) has been observed visiting and consuming the fruits of diverse group of plant species (Stiles \& Skutch, 2007), a reason for assuming that it is occupying the function of seed disperser due to its feeding habit; but it implies irregular dispersion patterns, conditioned to the existence of perching sites.

Related with the introduced fauna and its role in seed dispersal, Madriz-Masís (2009) reported feral pigs dispersing seeds of Annona glabra. They also had been observed eating fruits of $S$. holdridgei, but regenerations had never been found growing in their excrement, as happens with $A$. glabra. Rats are reported as potential seed dispersers including seeds of S. holdridgei (Madriz-Masís 2009); seeds are usually found in their burrows in trees or logs, but never a germinated seed has been observed. The white-tailed deer was reported as a major threat for tree species regenerations for its herbivore habit (Madriz-Masís, 2009). According to scarce reports and personal field observation over time, we do not consider introduced fauna as an efficient seed disperser, and they act more as seed predators. At least for C. pittieri, other potential seed dispersers in PNIC are ants and rats (Dalling, Forget, Lambert, Hulme, \& Wall, 2005; Murray \& Garcia, 2002), but their efficiency dispersing seeds is unknown.

The seed bank was indirectly evaluated through seed germination, and an important point to consider is that both $S$. holdridgei and C. pittieri are endemic; it makes comparison difficult and we can only assume a similar response of those continental sister species. In the case of $S$. holdridgei, and given that germination was poor, it can be assumed that the seed bank is exhausted. The reason for this could be found in the long period since the deforestation of the site in 1881. After such an extended period, and without seed dispersion from remaining forest sites, it is expected that all the seeds have, by far, exceeded their dormancy and viability periods, assuming periods similar to those of continental S. trichogyna, which is of 18 to 24 months (Hartshorn, 1978) or more than five months for Vantanea eplete McPherson, 1988 (Sautu, Baskin, Baskin, \& Condit, 2006). Garwood (1983) proposes that dormancy in tropical species has been replaced by the dispersion times; in the case of $S$. holdridgei, fructification takes place during most of the year, which ensures seed provisions.

Seed viability of Cecropia varies substantially. For C. insignis, C. obtusifolia and C. polyphlebia a little more than a year was reported (Alvarez-Buylla \& Martínez-Ramos, 1990; Dalling, Swaine, \& Garwood, 1998; Murray \& Garcia, 2002), little more than four years for C. sciadophylla (Holthuijzen \& Boerboom, 1982) and more than 62 months reported by Holthuijzen and Boerboom in Lamprecht, (1989). According to the spatial pattern of regeneration, the site condition and the exclusion fence were the factors that favoured the establishment of $C$. pittieri regeneration.

The remaining canopy species, Ocotea insularis (Meisn.) Mez, 1889 and Euterpe precatoria Mart. Var. longevaginata (Mart.) A.J. Hend., 1995, are bird-dispersed (Stevenson, Cardona, Acosta-Rojas, Henao-Díaz, \& Cárdenas, 2017), and face the same problems of lack of dispersers and an exhausted seed bank of $S$. holdridgei and $C$. pittieri.

Actions for restoration at the PNIC: The strategy to restore the area of the study includes a series of sequential actions. Firstly, herbivores need to be removed from the site. The canopy species are consumed by herbivores during the seedling and sapling stages and are unable to escape from branch-grazing until they outgrow the white-tailed deer. Secondly, E. gigas requires control which, according to the results of the trial, can be accomplished through cutting or uprooting given the low capability to sprout. But, if there are any remaining plants of E. gigas in the border of the restoring area, its shoots should be controlled, 
because they easily invade the restoration site. On third place, let the site respond, expecting that cutting the vegetation will promote the establishment of $C$. pittieri as a pioneer species, present in the soil bank, as well as dispersed. Lastly, once $C$. pittieri gives shade, introduce other canopy species such as $O$. insularis and $S$. holdridgei. As has been observed, growth of S. holdridgei is favoured under partial shade (Acosta-Vargas, unpublished), an expected condition of shade-tolerant species according to the report on S. trichogyna (Fernandez-Vega et al., 2017).

\section{CONCLUSIONS}

To restore the site, the treatment of vegetation cutting is the most appropriate, because both treatments - cutting and uprootingwere favourable and activated the regeneration of tree species in the same way, but cutting vegetation is easier than uprooting.

Herbivores have a negative impact on the forest and its regeneration, given their selective consumption habits towards arboreal species.

Grass species exhibit a high and rapid regeneration capacity in the site, which is useful for preventing erosion. However, grass species are undesirable because of the high risk of invading the site they pose.

Recovering the native forest demands an active restoration project, sustained over time, to overcome the filters detected of seed bank and dispersion, which are ineffective or absent.

Ethical statement: authors declare that they all agree with this publication and made significant contributions; that there is no conflict of interest of any kind; and that we followed all pertinent ethical and legal procedures and requirements. All financial sources are fully and clearly stated in the acknowledgements section. A signed document has been filed in the journal archives.

\section{ACKNOWLEDGEMENTS}

We thank the Vicerrectoría de Investigación del Tecnológico de Costa Rica for financing the project; the Área de Conservación Marina Cocos for their support to the research and the counterpart funds contributed; the personnel from the Isla del Coco National Park for their support; the personnel from the Escuela de Ingeniaría Forestal and the Centro de Investigación en Innovación Forestal for their support to the activities of the project. To Felipe Chacón for aerial photography. Also, many thanks to the anonymous reviewers who contributed to this article. To CONICET, PIP: 11220150100196.

\section{RESUMEN}

Efectividad de dos tratamientos para promover la regeneración de árboles: implicaciones para la restauración de bosques en el Parque Nacional Isla del Coco. Introducción: Isla del Coco es la única isla en el Pacífico oriental con bosques tropicales húmedos, albergando 296 especies de plantas, de las cuales un $22 \%$ son endémicas. De su ecología se conoce muy poco. El bosque fue degradado con la introducción de cerdos y venados cola blanca y por deforestación. Las áreas deforestadas hace más de 120 años nunca recuperaron el bosque nativo. Objetivo: Para analizar si el área deforestada mantiene su capacidad de recuperación, se evaluó la regeneración natural y los procesos ecológicos asociados. Metodología: Desde agosto de 2016 hasta junio de 2018, se monitoreó un ensayo de restauración, establecido como un diseño de bloques completos al azar. Los tratamientos incluyeron corte de vegetación, arranque de vegetación y controles. Se utilizó una cerca de exclusión para evitar los herbívoros. Resultados: No hubo diferencias en los tratamientos de corte y arranque de la vegetación para estimular la regeneración natural. Se registró la regeneración de dos especies de árboles: 35 individuos de Cecropia pittieri y tres de Sacoglottis holdridgei, ambas endémicas. La regeneración se estableció principalmente en los primeros 15 meses. Luego de aplicados los tratamientos, la estructura y composición de la vegetación cambió de arbustos dominados por Entada gigas (28\%) y Clidemia strigillosa (12\%), a pastos dominados por Paspalum conjugatum (39\%). Entada gigas tiene el mayor potencial de recolonización por su tasa de crecimiento de $1.6 \pm 0.2 \mathrm{~m} / \mathrm{mes}$. Conclusiones: Los filtros determinados asociados con la regeneración del bosque 
son los herbívoros; el banco de semillas de las especies arbóreas agotado y la dispersión de semillas escasa o nula, según la especie.

Palabras clave: herbívora, Isla del Coco, regeneración natural, restauración, venados cola blanca, cerdo.

\section{REFERENCES}

Acosta-Vargas, L. G. (2016). Population status of the tree Sacoglottis holdridgei (Humiriaceae) at Isla del Coco National Park, Costa Rica. Revista de Biología Tropical/International Journal of Tropical Biology and Conservation, 64(1), 263-275.

Alfaro, E. J. (2008). Ciclo diario y anual de variables troposféricas y oceánicas en la Isla del Coco, Costa Rica. Revista de Biología Tropical, 19-29. https://doi. org/10.15517/rbt.v56i2.26936

Alvarez-Buylla, E. R., \& Martínez-Ramos, M. (1990). Seed bank versus seed rain in the regeneration of a tropical pioneer tree. Oecologia, 84(3), 314-325. https://doi.org/10.1007/BF00329755

Bonilla-Mata, R., \& Acosta-Vargas, L. G. (2020). Dynamic and growth of the forests of the Isla del Coco National Park, Costa Rica. Revista de Biología Tropical, 68(Supl. 1), S89-S102.

Bufalo, F. S., Galetti, M., \& Culot, L. (2016). Seed dispersal by primates and implications for the conservation of a biodiversity hotspot, the Atlantic forest of South America. International Journal of Primatology, 37(3), 333-349.

Capizzi, D., Baccetti, N., \& Sposimo, P. (2010). Prioritizing rat eradication on islands by cost and effectiveness to protect nesting seabirds. Biological Conservation, 143(7), 1716-1727. https://doi. org/10.1016/j.biocon.2010.04.020

Carvalho, M. J. N., Silva, R. S., Rocha, A. E., \& Almeida, M. C. C. (2018). Levantamento fitossociológico do Mirim (Humiria balsamifera (Aubl.) A. St. Hil) em área de Restinga ocasionalmente alagada no projeto de assentamento Rio Pirangi, Morros-MA. Cadernos de Agroecologia, 13(1).

Chazdon, R. L., \& Guariguata, M. R. (2016). Natural regeneration as a tool for large-scale forest restoration in the tropics: prospects and challenges. Biotropica, 48(6), 716-730. https://doi.org/10.1111/btp.12381

Clarke, K. R. (1993). Non-parametric multivariate analyses of changes in community structure. Australian Journal of Ecology, 18(1), 117-143.

Cortés, J. (2008). Historia de la investigación marina de la Isla del Coco, Costa Rica. Revista de Biología Tropical, 56(2), 1-18.
Côté, S. D., Beguin, J., de Bellefeuille, S., Champagne, E., Thiffault, N., \& Tremblay, J.-P. (2014). Structuring effects of deer in boreal forest ecosystems. Advances in Ecology, 2014.

Cushman, J. H. (1995). Ecosystem-Level Consequences of Species Additions and Deletions on Islands. En P. M. Vitousek, L. L. Loope, \& H. Adsersen (Eds.), Islands: Biological Diversity and Ecosystem Function (pp. 135147). https://doi.org/10.1007/978-3-642-78963-2_11

Dalling, J. W., Forget, P., Lambert, J. E., Hulme, P. E., \& Wall, S. B. V. (2005). The fate of seed banks: factors influencing seed survival for light-demanding species in moist tropical forests. https:/doi. org/10.1079/9780851998060.0031

Dalling, J. W., Swaine, M. D., \& Garwood, N. C. (1998). Dispersal patterns and seed bank dynamics of pioneer trees in moist tropical forest. Ecology, 79(2), 564-578.

Donlan, C. J., Luque, G. M., \& Wilcox, C. (2015). Maximizing Return on Investment for Island Restoration and Species Conservation: Maximizing return on investment for island restoration. Conservation Letters, 8(3), 171-179. https://doi.org/10.1111/conl.12126

Donlan, C. J., Tershy, B. R., Keitt, B. S., Wood, B., Sanchez, J. A., Weinstein, A., ... Alguilar, J. L. (2000). Island conservation action in northwest Mexico. Proceedings of the Fifth California Islands Symposium, 330-338.

Estrada-Chavaría, A., Sánchez-González. J., \& RodríguezGonzález, A. (2020). Catálogo actualizado de las plantas vasculares del Parque Nacional Isla del Coco, Costa Rica. Revista de Biología Tropical, 68(S1), S73-S88.

Fernandez-Vega, J., Covey, K. R., \& Ashton, M. S. (2017). Tamm Review: large-scale infrequent disturbances and their role in regenerating shade-intolerant tree species in Mesoamerican rainforests: Implications for sustainable forest management. Forest Ecology and Management, 395, 48-68.

Fleming, T. H., \& Williams, C. F. (1990). Phenology, seed dispersal, and recruitment in Cecropia peltata (Moraceae) in Costa Rican tropical dry forest. Journal of Tropical Ecology, 6(2), 163-178.

Flory, S. L., \& Clay, K. (2010a). Non-native grass invasion alters native plant composition in experimental communities. Biological Invasions, 12(5), 1285-1294.

Flory, S. L., \& Clay, K. (2010b). Non-native grass invasion suppresses forest succession. Oecologia, 164(4), 1029-1038.

Friday, J. B., Cordell, S., Giardina, C. P., Inman-Narahari, F., Koch, N., Leary, J. J., ... Trauernicht, C. (2015). Future directions for forest restoration in Hawai 'i. New Forests, 46(5-6), 733-746. 
Friedman, M. (1937). The Use of Ranks to Avoid the Assumption of Normality Implicit in the Analysis of Variance. Journal of the American Statistical Association, 32(200), 675-701. https://doi.org/10.1080/01 621459.1937 .10503522

Garwood, N. C. (1983). Seed germination in a seasonal tropical forest in Panama: a community study. Ecological Monographs, 53(2), 159-181.

Gill, R. M. A., \& Beardall, V. (2001). The impact of deer on woodlands: the effects of browsing and seed dispersal on vegetation structure and composition. Forestry: An International Journal of Forest Research, 74(3), 209-218.

Goldstein, J. H., Pejchar, L., \& Daily, G. C. (2008). Using return-on-investment to guide restoration: a case study from Hawaii. Conservation Letters, 1(5), 236-243. https://doi.org/10.1111/j.1755-263X.2008.00031.x

Green, P. T., O’Dowd, D. J., \& Lake, P. S. (1997). Control of seedling recruitment by land crabs in rain forest on a remote oceanic island. Ecology, 78(8), 2474-2486.

Hammel, B. E., Grayum, M. H., Herrera, C., \& Zamora, N. (2015). Manual de Plantas de Costa Rica. Dicotiledóneas (Halogaraceae-Phytolaccaceae). Vol VI. Monographs in Systematic Botany from the Missouri Botanical Garden, 131, 1-657.

Hammer, Ø., Harper, D. A. T., \& Ryan, P. D. (2001). Paleontological statistics software: package for education and data analysis. Palaeontologia Electronica, (4).

Hartshorn, G. S. (1978). Tree falls and tropical forest dynamics. En P. B. Tomlinson \& M. H. Zimmermann (Eds.), Tropical Trees as Living Systems (pp. 617638). UK: Cambridge Univesity Press.

Herrera, W. (1986). Clima de Costa Rica. Vol. 2. Vegetación y Clima de Costa Rica. San José, Costa Rica: Editorial Universidad Estatal a Distancia (EUNED).

Holthuijzen, A. M. A., \& Boerboom, J. H. A. (1982). The Cecropia Seedbank in the Surinam Lowland Rain Forest. Biotropica, 14(1), 62. https://doi. org/10.2307/2387761

Horsley, T. W., Bicknell, J. E., Lim, B. K., \& Ammerman, L. K. (2015). Seed dispersal by frugivorous bats in Central Guyana and a description of previously unknown plant-animal interactions. Acta Chiropterologica, 17(2), 331-336.

Jones, H. P., Holmes, N. D., Butchart, S. H. M., Tershy, B. R., Kappes, P. J., Corkery, I., ... Croll, D. A. (2016). Invasive mammal eradication on islands results in substantial conservation gains. Proceedings of the National Academy of Sciences, 113(15), 4033-4038. https://doi.org/10.1073/pnas.1521179113
Koda, R., \& Fujita, N. (2011). Is deer herbivory directly proportional to deer population density? Comparison of deer feeding frequencies among six forests with different deer density. Forest Ecology and Management, 262(3), 432-439.

Lamprecht, H. (1989). Silviculture in the tropics: tropical forest ecosystems and their tree species. German, DE: GTZ.

Levene, H. (1961). Robust tests for equality of variances. Contributions to probability and statistics. Essays in honor of Harold Hotelling.

Litton, C. M., Sandquist, D. R., \& Cordell, S. (2006). Effects of non-native grass invasion on aboveground carbon pools and tree population structure in a tropical dry forest of Hawaii. Forest ecology and management, 231(1-3), 105-113.

Losos, J. B., \& Ricklefs, R. E. (2009). Adaptation and diversification on islands. Nature, 457(7231), 830.

Madriz-Masís, J. P. (2009). El Parque Nacional Isla del Coco (PNIC): una isla oceánica invadida. Biocenosis, 22(1-2), 61-72.

Medellin, R. A. (1994). Seed dispersal of Cecropia obtusifolia by two species of opossums in the Selva Lacandona, Chiapas, Mexico. Biotropica, 400-407.

Montoya. (2016). Isla del Coco: Marine Ecosystem. En M. Kappelle (Ed.), Costa Rican Ecosystems. University of Chicago Press.

Murray, K. G., \& Garcia, J. M. (2002). Contributions of seed dispersal and demography to recruitment limitation in a Costa Rican cloud forest. En D. J. Levey, W. R. Silva, \& M. Galetti (Eds.), Seed dispersal and frugivory: ecology, evolution and conservation (pp. 323-338). UK: CABI International.

Newton, A. C. (2007). Forest ecology and conservation. A handbook of techniques. Reino Unido: Oxford University Press.

O’Dowd, D. J., Green, P. T., \& Lake, P. S. (2003). Invasional 'meltdown'on an oceanic island. Ecology Letters, 6(9), 812-817.

Porras Jiménez, M. A. (2012). Dinámica de los bosques del Parque Nacional Isla del Coco, Área de Conservación Marina Isla del Coco. Instituto Tecnológico de Costa Rica, Cartago, Costa Rica.

Porras-Jiménez, M. A., Acosta-Vargas, L. G., CastilloUgalde, M., \& Quesada-Monge, R. (2014). Estructura y composición florística del bosque nuboso de la Isla del Coco. Revista Tecnología en Marcha, 27, 22-36.

Relva, M. A., Nunez, M. A., \& Simberloff, D. (2010). Introduced deer reduce native plant cover and facilitate invasion of non-native tree species: evidence for 
invasional meltdown. Biological Invasions, 12(2), 303-311.

Rojas, W., \& Alvarado, G. E. (2012). Marco geológico y tectónico de la Isla del Coco y la región marítima circunvecina, Costa Rica. Revista de Biología Tropical, 15-32. https://doi.org/10.15517/rbt.v60i3.28306

Rooney, T. P., \& Waller, D. M. (2003). Direct and indirect effects of white-tailed deer in forest ecosystems. Forest ecology and management, 181(1-2), 165-176.

Sánchez Pacheco, J. Á., Tershy, B., \& Aguilar, J. L. (2000). Acciones de conservación de las islas de México. Gaceta Ecológica, (56).

Sautu, A., Baskin, J. M., Baskin, C. C., \& Condit, R. (2006). Studies on the seed biology of 100 native species of trees in a seasonal moist tropical forest, Panama, Central America. Forest Ecology and Management, 234(1-3), 245-263. https://doi.org/10.1016/j. foreco.2006.07.006

Shapiro, S. S., \& Wilk, M. B. (1965). An analysis of variance test for normality (complete samples). Biometrika, 52(3-4), 591-611.

Sierra, C. (2001). El cerdo cimarrón (Sus scrofa, Suidae) en la Isla del Coco, Costa Rica: Escarbaduras, alteraciones al suelo y erosión. Revista de Biología Tropical, 49(3-4), 1158-1170.

Smith-Ramírez, C., Vargas, R., Castillo, J., Mora, J. P., \& Arellano-Cataldo, G. (2017). Woody plant invasions and restoration in forests of island ecosystems: lessons from Robinson Crusoe Island, Chile. Biodiversity and Conservation, 26(7), 1507-1524. https://doi. org/10.1007/s10531-017-1317-9
Stevenson, P. R., Cardona, L. M., Acosta-Rojas, D. C., Henao-Díaz, F., \& Cárdenas, S. (2017). Diet of oilbirds (Steatornis caripensis) in Cueva de los Guácharos National Park (Colombia): temporal variation in fruit consumption, dispersal, and seed morphology. Ornitología Neotropical, 28, 295-307.

Stiles, F. G., \& Skutch, A. F. (2007). Guía de aves de Costa Rica (2. ${ }^{\mathrm{a}}$ ed.). Costa Rica: Editorial INBio.

Trusty, J. L., Kesler, H. C., \& Delgado, G. H. (2006). Vascular flora of Isla del Coco, Costa Rica. ProceedingsCalifornia Academy of Sciences, 57(1/11), 247.

UNESCO. (2019). Cocos Island National Park - UNESCO World Heritage Centre. Recuperado 10 de mayo de 2019, de https://whc.unesco.org/en/list/820

Veitch, C. R., Clout, M. N., Martin, A. R., Russell, J. C., \& West, C. J. (Eds.). (2019). Island invasives: scaling up to meet the challenge. https://doi.org/10.2305/ IUCN.CH.2019.SSC-OP.62.en

Weller, S. G., Sakai, A. K., Clark, M., Lorence, D. H., Flynn, T., Kishida, W., ... Wood, K. (2018). The effects of introduced ungulates on native and alien plant species in an island ecosystem: Implications for change in a diverse mesic forest in the Hawaiian Islands. Forest ecology and management, 409, 518-526.

Whitmore, T. C. (1998). Potential Impact of Climatic Change on Tropical Rain Forest Seedlings and Forest Regeneration. En A. Markham (Ed.), Potential Impacts of Climate Change on Tropical Forest Ecosystems (pp. 289-298). https://doi. org/10.1007/978-94-017-2730-3_13

See Digital Appendix at: / Ver Apéndice digital en: revistas.ucr.ac.cr 